\title{
The Determinant of Economic Growth Evidence from Benin: Time Series Analysis from 1970 to 2017
}

http://doi.org/10.21272/fmir.3(1).63-74.2019

\section{Dossou Toyo Amegnonna Marcel}

$\mathrm{PhD}$ candidate in School of Economics in Southwestern University of Finance and Economics, China

\begin{abstract}
Financial development is part of the private sector development strategy to stimulate economic growth and reduce poverty. So, the paper attempts to find out the determinant of economy growth and the explanatory variables, such as, the foreign direct investment, government expenditure, consumer price index and trade openness in Benin. Using time series as the econometric model and the data during 1970 and 2017 for the study. In addition, the technique that implemented to estimate the model was Ordinary Least Square. The result showed that the foreign direct investment and consumer index price have significantly and positively impact the Benin's economy growth but the trade openness and the government expenditure have significantly and negatively impacted the Benin's economy growth. I suggest that the government must invest more in infrastructure to attract more foreign direct investment. In term of trade Benin's policymaker should promote the local products and export to the world to adjust the balance between the import and export.
\end{abstract}

Key words: Economy growth, Cointegration, Causality, Investment.

JEL Classification: G15, O1, O10.

Cite as: D. T. Am. Marcel. (2019). The Determinant of Economic Growth Evidence from Benin: Time Series Analysis from 1970 to 2017. Financial Markets, Institutions and Risks, 3(1), 63-74. http://doi.org/10.21272/fmir.3(1).63-74.2019

(C) The Author, 2019. This article is published with open access at Sumy State University.

\section{Introduction}

The purpose of any government is to promote the development and welfare of the country. Moreover, Economic growth is the main indicators to the prosperity of any country. Countries that have achieved strong economic growth have been able to alleviate poverty (H., et al., 2012). Economy growth is the outcome of a combination of many factors among (Gnansounou, 2014).in the past decade Benin has known some progresses by making strong macroeconomic stability in term of GDP growth, it grew up to 5.6 percent in 2012 and reached 5.6 percent in 2013 (Pigato, 2014). Benin's economy relies heavily on its informal re-export and transit trade with Nigeria, which makes up roughly $20 \%$ of its GDP, and on agriculture. GDP growth accelerated from $4.0 \%$ in 2016 to $5.6 \%$ in 2017 (2.7\% per capita), driven by a vibrant agricultural sector buoyed by record cotton production, an increase in public investment (particularly infrastructure), and the strong performance of the service sector due to economic recovery in Nigeria. Inflation turned positive and averaged $0.1 \%$ in 2017 (versus $-0.8 \%$ in 2016) due to rising oil and food prices. The current account deficit widened-from $9 \%$ in 2016 to $11.00 \%$ in 2017 -due to the impact of infrastructure and energy-related imports. Exports increased faster than GDP but at a slower pace than imports. The primary deficit narrowed from $4.8 \%$ of GDP in 2016 to $3.9 \%$ in 2017 . However, the overall fiscal deficit fell only slightly-from to $6.0 \%$ of GDP in 2016 to $5.9 \%$ in 2017 -because of the burden of higher interest. (Nikolaos, et al., n.d.) According to their view economy theory has a large part of causality relationship between exports and economic growth. They also found that export consist one of the key determinants of economy growth and going up of export contribute to the economy growth. However, there are also some other factors, which affect the economic growth. Ricardo in his demonstration in 1817 notes that the commerce facilitates products output with a comparative advantage in a country resulting to a higher level of national wealth. In the general case investment, consumption, government expenditure and the trade balance are considered the main key of the determinant of the economic growth but view the condition of some countries we are the weakness of its economy growth. In this paper we want to know which the main determinant that pushes on the economy growth. Several others studies, including Feder, Ram, and Salvatore and Hatcher; have analyzed the exportled economic growth hypothesis. They argued that exports push up factor productivity because of better utilization of capacity and economies of scale. They also argued that exports are likely to diminish foreignexchange constraints and thereby promote importation of better technologies and production methods. 
Financial Markets, Institutions and Risks, Volume 3, Issue 1, 2019

ISSN (online) - 2521-1242 ISSN (print) - 2521-1250

Grossman and Helpman argued that open trade regimes go hand-in-hand with good investment climates, technology externalities, and learning effects. The purpose of this paper is to know the determinant of economic growth in Benin. Specifically, it will provide some answers to the following questions: what is the relationship between economic growth and government expenditure? What is the relationship between economic growth and inflation? What is the relationship between economic growth and DFI? What is the relationship between economic growth and export?

The framework of the paper is as follows. Section 2 reviews the literature on the determinant of economic growth. Section 3 provides a description of the methodology. Section 4 econometric estimation techniques, Section 4 Econometric findings and interpretations, Section 5 concluding remarks.

\section{Literature review}

In the past most studies have talked about the determinant of economy growth. Interest in the relationship between economic growth and FDI has increased in recent years because of the non-industrialization of developed countries and the internationalization of production processes. In the theoretical literature, endogenous growth models give weak explanations of the role of FDI in growth, which is associated with increased technological capital and infrastructure and the generation of employment. In general, investment plays a key role in the accumulation of physical capital and the formation of human capital. (Anwar, 2010) Studied that the effect of the FDI on economic growth is greater when the capital human is skilled, that means more reducing technological gap between local and foreign firms. Further, when FDI is complemented with domestic investment it promotes the development of the firms (Tan, 2016. .). The FDI can excite technology transfer which tends to grow the productive efficiency of factors. It is evident to think that increases in the technology translate into improved productivity of the labor force. If economic growth is conducted by innovation as argued by (Aghion, 1998). The need for FDI to push forward the development is proved given the main roles that technology and knowledge play in increasing production levels ( (Barro, .2001); (Lucas, 1988.)).( (Tounde Paterne \& Gbongl, 2016), regarding their view Economic growth is the increase in the inflation-adjusted market value of the goods and services produced by an economy over time. It is conventionally measured as the percent rate of increase in real gross domestic product, or real GDP. Of more importance is the growth of the ratio of GDP to population (GDP per capita, which is also called per capita income). They also said that economic growth per capita is usually conducted by improvements in productivity. Increased productivity means producing more goods and services using the same inputs of labor, capital, energy, and/or materials. (Daniel H. \& Coro, 2015) Investigated that the long run determinant of growth to foreign direct investment is considered as endogenous growth model. With their knowledge the growth rate of technology in the Solow model extended to include technology equals the long-run growth rate of GDP per capita. ${ }^{1}$ Technology is exogenous in the Solow model. Thus, if technology is omitted, the longrun growth. Human capital, public infrastructure and technology are considered the principal determinant growth. The institutional background is also important in understanding differences within countries. (Temple, 1999) Emphasized that research, development and human capital, and others principals variables. Moreover, domestic governance together with macroeconomic policies and financial globalization seems to be conducive to good growth. (E. , et al., 1997) Said that Technology diffusion can take place through a variety of channels that involve the transmission of ideas and new technologies. Imports of high-technology products, adoption of foreign technology and acquisition of human capital through various means are certainly important conduits for the international diffusion of technology ${ }^{2}$. Besides these channels, foreign direct investment by multinational corporations (MNCs) is considered to be a major channel for the access to advanced technologies by developing countries. They also found the key role of technology as the progress of the human capital's skill. (Rafael, et al., 2017) According to their view foreign direct investment provides more gains to the investors (diminished cost, made large the market) and the host country receives more (technology transfers, human capital transfers and generation of jobs)

The empirical literature on the effect of economic growth shows contradictory results. Firstly, there are several studies that show a positive impact of FDI on economic growth. (Chen \& Feng, 2000) Studied the effect of investment, inflation state-owned firms, trade (exports plus imports) higher education enrolment in economic

\footnotetext{
${ }^{1}$ Neoclassical models of growth as well as endogenous growth models provide ground for most of the empirical work on the FDI-growth relationship. This relationship has been studied by explaining different channels: determinants of growth, determinants of FDI, role of multinational firms in host countries, and causality between the two variables (Chowdhury and Mavrotas 2005). The endogenous growth literature points out the increments in economic growth through capital formation, technology transfer, and increased level of education and knowledge in the population.

2 See Easterly et al. (1994) for a framework incorporating the roles of technology adoption through international trade and human capital accumulation as determinants of economic growth.
} 
Financial Markets, Institutions and Risks, Volume 3, Issue 1, 2019 ISSN (online) - 2521-1242 ISSN (print) - 2521-1250

growth in China. Using provincial panel data, the study found education and trades have been positively significant in the annual average of GDP per capita. State-owned firms and Inflation, on the other hand, were negatively and significantly associated with economic growth. Their study concluded, therefore, that private firms, foreign trade and education were important determinants of China's long-run economic growth.

\section{Data and Methodology}

The data mainly come from the database of the World Bank, particularly Africa Database CD-ROM 2018, and World Bank Indicators 2018. As for estimating, it will cover the period 1970 to 2017. To understand the determinant of economic growth, several econometric methods are used. We will make a brief critical review of these methods before proposing the methodology we use in our work.

\section{3-1 brief review of econometric methods}

In the case of specific studies to countries, the use of time series is one of the appropriate methods (Zhao, 1995) ; (De MELLO, 1999)The principal arguments for these are that panels which were applied implicitly require or imply a common economic structure and a similar production technology between countries, while the time series used to highlight the specificities of each country studied. Indeed, the economic growth of a country is not only influenced by FDI and another factors production. It is also affected by a host of internal policies such as education policies, fiscal and external, which may be as many channels through which FDI profits can be maximized. $(\mathrm{Hu}, 2003)$ Another suitable method is the use of linear simultaneous equations system. Our econometric model is derived from a production function in which the level of a country's productivity depends on FDI, trade, domestic investment, human capital, and initial.

Gross domestic product (GDP) per capita.

$$
\begin{aligned}
& Y=\alpha+\alpha_{1} X_{1}+\alpha_{2} X_{2}+\alpha_{3} X_{3}+\alpha_{4} X_{4}+\varepsilon_{t} \\
& \log G D P=\alpha+\alpha_{1} \log G O V+\alpha_{2} \log C P I+\alpha_{3} \log F D I+\alpha_{4} \log E X \quad t \\
& \text { Where, }
\end{aligned}
$$

$\mathrm{Y}=\mathrm{GDP}=\mathrm{GDP}$ per capita growth (annual \%) X1 = GOV = Final consumption expenditure (annual \% growth) $\mathrm{X} 2=\mathrm{CPI}=$ Inflation, GDP deflator (annual \%) X3 = FDI = Foreign direct investment, net inflows (\% of GDP) $\mathrm{X} 4=\mathrm{EX}=$ Trade $(\%$ of GDP)

The relationship between Foreign Direct Investment (FDI) and Gross Domestic Product (GDP). Based on the past paper, the sign expected that there is positive relation between FDI and GDP. This is because for every country's economic growth is depended on the investments which are by growing in assets and infrastructure. In addition, when FDI increase it will also increase the GDP of the country. (Iqbal, N, et al., 2014) Were supported that the relation between FDI and GDP is positively significant in the past decades. Besides, (GuechHeang, 2013) also stated thatthere is a significantly positive relation between FDI and GDP in the long run. In addition, FDI has influence the GDP positively which this statement is supported by (Sandalcilar, 2012).

The relationship between Consumer Price Index (CPI) and Gross Domestic Product (GDP). regarding to the past empirical studies, the inflation and GDP is expected to have a negative relationship. As supported by Hefer (1989), when the country's price of goods and services increase and the currency value depreciate, then the inflation is going to happen in that particular country. Hence, consumers will head for less in spending and this behavior will affect the growth of economic negatively which means that it will slow down the progress rate of economic. Therefore, this study expects that the inflation will bring negative impact to GDP. As supported by Caglayan, Kandemir and Mouratidis (2012), the rate of inflation will influence the real GDP negatively. In addition, Kasidiand Mwakanemela (2013) also supported that the inflation would bring a negative impact toward the GDP. In other words, the rise of inflation rate might decelerate the growth of economic. In addition, the researcher, Inyiama (2013) had also investigated that the inflation and GDP has negative correlation.

The relationship between Government Expenditure (GOV) and Gross DomesticProduct (GDP). According to (Rana, 2014) there are opposite, he also tried to explain the concept of Keynes which says higher government spending will produce higher economic growth. To argue this concept, he gives again the hypothesis of wagner which says that the development of an industrial economy will be followed by an increased share of public expenditure in gross national product. In addition the results of his study show that a significant $\log$ runs relationship between government expenditure and gross domestic product in 
Financial Markets, Institutions and Risks, Volume 3, Issue 1, 2019

ISSN (online) - 2521-1242 ISSN (print) - 2521-1250

Bangladesh. (Raziiakhan, et al., 2007) Investigated in the period 2000Q1 to 2013Q4 and the result shows there is long relationship between GDP and government expenditure in both countries showing by granger causality test. Government expenditure is key objective an economy as said (Danladi, et al., 2015). In their study the size of government expenditure can increase the economy.

The relationship between trade openness and Gross Domestic Product (GDP). (Hlalefang Khobai \& Clement Moyo, 2017). Determined the long run link between trade openness and economy growth in Ghana and Nigeria. Using as a data the period from 1980 to 2016 and the result show that there is not significant between trade openness and economy growth between two countries at $1 \%$ level. According to (Wajahat Ali \& Azrai Abdullah , 2015) study there are two kind of relationship. In short run there have positive relationship and ne negative in long run. (KHALID, 2016) Studied the relationship between trade openness and economy growth in turkey over the sample $1960-2014$ and the result confirms the co integration between the series.in addition in short run trade openness has positive effect in economy growth but in the long run does not exist.

Table 1. Correlation analysis

\begin{tabular}{|l|c|c|c|c|}
\hline & LOG(CPI) & LOG(FDI) & LOG(GOV) & LOG(TO) \\
\hline LOG(CPI) & 1.000000 & 0.995552 & 0.986858 & 0.982342 \\
\hline LOG(FDI) & 0.995552 & 1.000000 & 0.999084 & 0.961775 \\
\hline LOG(GOV) & 0.986858 & 0.999084 & 1.0000000 & 0.961775 \\
\hline LOG(TO) & 0.982342 & 0.961775 & 0.961775 & 1.000000 \\
\hline
\end{tabular}

Source: author from Eviews.

Coefficient of correlation, where $i=1,2,3,4 \& \mathrm{j}=1,2,3,4$.

The relationship between the the foreign direct investment, consumer price index, government expenditure and trade openness are positive as show the coefficient in the table. That means there are correlated in themself.

\section{Interpretations of the finding}

As show the table the FDI has significantly and positively effect to Benin's economy growth. That means when the FDI increases by $10 \%$ automatically the growth rate will increase at $21.77 \%$ Argued by (Dumor Koffi, et al., 2016). In their study they found that the FDI has positive impact on economy growth. According to the result showing by the table the consumer index price has positively and significantly effect to the economy growth in Benin means that $10 \%$ increase in CPI will lead the growth rate to also increase by $17.35 \%$. But exceeding $17.35 \%$ the consumer price index will have a negative impact on economy growth defended by (Hasanov, 2011). According to (Mahmoud, 2015) study the consumer price index has unidirectional causality with economy growth. The government expenditure and trade openness have negatively and significantly impacted the economy growth in Benin. That means $10 \%$ increase in government expenditure will lead to a decline the growth rate in order of $37.02 \%$. In the same direction with the trade openness $10 \%$ increase in trade openness will decline the growth rate at 1.49\%. Further (Marilyne Huchet-Bourdon, et al., n.d.) studied the non-linear relationship between export and growth and suggested that the promoting of the local product via the exportation. According to result the Benin's economy depend more the import than export. So, I suggest that to the policymaker to promote more the local product to the world like win-win cooperation as china and U.S. in case of government expenditure, the government has more deficit in term education, infrastuture etc. Argued by (Hasnul, 2015) according to his study.

\section{Economic growth in Benin}

According to the budget deficit crept up from 5.6\% of GDP in 2016 to an estimated 5.9\% in 2017. With the government expressing interest in reining in spending, the deficit is projected to decline to $4.8 \%$ in 2018 and $3.1 \%$ in 2019 . The tighter fiscal policy that took effect in 2017 aims to achieve the $3 \%$ target for the budget deficit set by the West African Economic and Monetary Union (WAEMU). According to an International Monetary Fund (IMF) debt sustainability analysis, Benin moved from a low risk to a moderate risk of debt distress. Public debt increased from 50.3\% of GDP in 2016 to 53.4\% in 2017 due to higher spending related to implementation of the Government Action Plan. Government efforts to mobilize resources through a bond issue, as well as technical and financial partnerships, are expected to reduce public debt to $51.5 \%$ of GDP from 2019 onward. Due to WAEMU's policy of price stability, good performance in agriculture, and weak oil prices, inflation is likely to remain below the 3\% target. The current account deficit worsened from $7.3 \%$ of GDP in 2016 to an estimated 9.5\% in 2017 but is projected to improve slightly in 2018 and 2019. 


\section{Econometric Analysis}

Heteroscedasticity. Gujarati and Porter (2009) had supported that the error terms do not have a constant variance or equal spread is known as heteroscedasticity. There are many methods can be used to get out the presence of heteroscedasticity, which included Park test, Glejser test, White test, BreuschPagan, Goldfeld-Quandt test and ARCH test. Even though heteroscedasticity does not undermine the unbiasedness and conformity properties of the OLS estimators, again they are no longer efficient. When heteroscedasticity occurs, it brings few consequences to the OLS estimators. For instance, OLS estimators are no longer the best because it violates the minimum variance. Not only that, the OLS method would underestimate the variances. If heteroscedasticity happen, variance of estimated slope coefficient will decline and the standard error of estimated slope coefficient will decline as well.

This would provoke the value of t-test statistic and F-test statistic increase. Therefore, the hypothesis testing will become invalid. However, the OLS estimators are again unbiased and consistent because there are no independent variables correlated with the error term. Besides, there have some methods can be used to overcome the heteroscedasticity problem. For instance, by using the Generalized Least Squares (GLS), which mean divide the whole model with variance, it could restrain the heteroscedasticity problem. Not only GLS method, Weighted Least Squares (WLS) also one of the remedies that may use to overcome the heteroscedasticity problem. It is just multiplying a certain number with whole model which can make the variance become constant or White's heteroscedasticity-corrected variances and standard error by using EViews. H0: The model is homoscedasticity.H1: The model is heteroscedasticity. In significance tests, the null hypothesis will be rejected if the test statistic value lies in the critical region which means that the test is statistically significant. Nevertheless, the test will be insignificant if the value of the test statistic lies in the acceptance region (Gujarati \& Porter, 2009). In this study, the null hypothesis will be rejected if ARCH statistic is more than upper critical value. Otherwise, do not reject null hypothesis. Additionally, the P-value also consider as another method to determine the significance of hypothesis testing. Reject null hypothesis when P-value less than significant level. Thus, if null hypothesis is rejected, then the model is suffering from the heteroscedasticity problem. Autocorrelation is given as the correlation between error terms in the past and at present time. It can be separated into pure autocorrelation and impure correlation. Pure autocorrelation is provoked by the distribution of error term where there is a problem happen in a variable or data measurement. Impure autocorrelation is provoked by specification bias which is error make by human being such as omitted important variable, included unimportant variable in the model, incorrect functional form of the model or cobbled phenomena. If there is autocorrelation problem in the error terms, some consequences will happen in the OLS estimators. The OLS estimators are still unbiased which is the mean of estimated parameter is equal to the actual parameter, because it is not influence by variance, it only influences by the sample size. However, the OLS estimators will be inefficient, therefore it is no longer the best, due to the variances is no longer minimum. It may cause all the hypothesis testing become invalid due to the OLS method underestimate or overestimate the variance. Where, before overcome the autocorrelation problem, it is a must to identify the autocorrelation problem whether it is pure or impure autocorrelation. In order to confirm there is pure autocorrelation, it must be made sure that there is no specification bias in the model which the residual without any patterns. After confirm the autocorrelation problem is pure, there are two methods can be used to overcome it which are Cochrane-Orcutt procedure or Newey-West to adjust the standard errors. If the sample size is large enough, then it is appropriate to use Newey-west to adjust standard errors by using EVeiws to overcome it (Gujarati, D.N. \& Porter, D.C, n.d.). The Durbin-Watson (DW) test which published in 1950 and it is possibly the best-known serial correlation test. The limitations mentioned that DW statistic cannot be used to estimate the residual autocorrelation when an explanatory variable is a lagged dependent variable in the regression (Levich, R. M \& Rizzo, R. C, 1998). For the sake of overcome this problem, Durbin (1970) put forward the modification, the $\mathrm{h}$ test which under the null hypothesis is approximately normally distributed with unit variance. In addition to avoid several the traps of the DW d test of the autocorrelation, statisticians Breusch and Godfrey have developed a test of autocorrelation that is general in the sense that it allows for random variable, order autoregressive schemes and simple or higher-order moving averages of white noise error terms. The Breush-Godfrey (BG) test also called the Lagrange Multiplier (LM) test (Gujarati, D.N. \& Porter, D.C, n.d.).H0: The model is no autocorrelation. H1: The model is autocorrelation.

In significance tests, if the test statistic value is lies in the critical region which means that the test is statistically significant where the null hypothesis will be rejected. Nevertheless, the test will be insignificant if the test statistic value lies in the acceptance region. On the other hand, P-value also acted as another method to find out the significance of hypothesis testing. Reject null hypothesis when P-value less than significant 
Financial Markets, Institutions and Risks, Volume 3, Issue 1, 2019

ISSN (online) - 2521-1242 ISSN (print) - 2521-1250

level. Thus, if does not reject the null hypothesis which means that the model is no suffered from autocorrelation.

The co-integration tests. Referring to the table4 I find the economy growth and foreign direct investment are strongly co-integrated at the critical value 0.05 . Argued by (GuechHeang, 2013) who investigated that the relationship between FDI and GDP and there are strongly significant. Referring to the table5 the result shows that the economy and consumer prix index are co-integrated at the critical value 0.05 .the same to table $6 \& 7$ are showing respectively the cointegration between economy growth and trade benin and others countries and also the government expenditure and economy growth.

Conclusion. My paper aims to find out the determinant of Benin's economy growth. According to the study I find that the consumer price index and foreign direct investment are the real key determinant on economy growth in Benin. My paper enriches empirical research on the determinant on Benin's economic growth by using time series via linear equation. The historical evidence suggests valuable lessons for Benin growth. First the government will invest more in infrastructure to attract more foreign direct investment to boost the country economy which can promote the local product via FDI. Also, the country's export. The result shows also the economy growth and explanatories variable are co-integrated at $5 \%$.

\section{Recommendations}

Regarding the result of paper, the policymaker should promote the local products via the export as china and U.S. not only consider the import as the good product. The government should also invest more to the infrastructure to attract more the foreign direct investment to boost the economy

\section{Reference}

1. Aghion, P. H. P. (1998). Endogenous Growth. MIT Press.

2. Anwar, S. N. L. (2010). Foreign direct investment and economic growth in Vietnam.,. s.l.: Asia Pac. Bus. Rev. 16 183-202.

3. Barro, R. (2001). Human capital and growth. s. 1. Amer. Econ. Rev91 (2), 12-17.

4. Chen, B. \& Feng, Y. (2000). Determinants of Economic Grwoth in china: Private enterprise, education and s.l.: China Economic Review 11, 1-15.

5. Daniel H., V.-J. \& Coro, C. (2015). Long-Run Determinants of Economicgrowth In South America. s.1. Journal of Applied Economics, 19(1), 169-192.

6. Danladi, J. D., K. J. Akomolafe, O. S. Olarinde \& N. L. Anyadiegwu, (2015). Government Expenditure and Its Implication for Economic Growth: Evidence from Nigeria. s.l. Journal of Economics and Sustainable Development.

7. De MELLO, L. (1999). Foreign Direct I nv e st me nt -Led Growth: Evidence from T i m e. s.l. Oxford Economic Papers, 51, 133-151.

8. Dumor Koffi, Zonon Ifred Baba Tounde Paterne \& Gbongli komlan, (2016). Impact of the Foreign Direct Investment on Economic Growth in Benin: A Cointegration Analysis. s.l. Journal of Economics and Sustainable Development.

9. E., B., J., D. G. \& J-W. L. (1997). How does foreign direct investment affect economic growth? s.1. Journal of International Economics 45 (1998) 115-135.

10. Galaye, N. \& Helian, X., (2016). Impact of Foreign Direct Investment (FDI) on Economic Growth inWAEMU from 1990 to 2012. International Journal of Financial Research, 33- 43.

11. Gnansounou, S. U., (2014). the determinant of private investment in benin: A panel Data Analysis. African Economic Research Consortium, Nairobi, 1-40.

12. GuechHeang, L. \&. M. P., (2013). The Case of Cambodia.The Relationship between Gross Domestic Product and Foreign Direct Investment: s.1.: KASBIT Journal ofManagement \& Social Science, 6, 87-99.

13. Gujarati, D.N. \& Porter, D.C, n.d. Basic Econometrics. Boston, MA: (2009). (5th ed.).

14. H., A., SA, D. \& Y., A., (2012). The determinants of long-term economic growth in Ghana from 19602007. Journal of Research in Economics and International Finance (JREIF). 1(5), 141-149, November 2012.

15. Hasanov, F., (2011). Relationship between inflation and economic growth in Azerbaijani economy: is there any threshold effect? Munich Personal RePEc Archive.

16. Hasnul, A. G. (2015). The effects of government expenditure on economic growth: the case of Malaysia. s.l.: Munich Personal RePEc Archive.

17. Hlalefang Khobai \& Clement Moyo. (2017). The relationship between trade openness and economic growth: The case of Ghana and Nigeria. s.l.: Munich Personal RePEc Archive. 
Financial Markets, Institutions and Risks, Volume 3, Issue 1, 2019 ISSN (online) - 2521-1242 ISSN (print) - 2521-1250

18. Hu, T. S. Y. a. A. Y. (2003). Domestic Firms Benefit from Foreign Direct Investment? Initial Evidence from Chinese Manufacturing. Do Domestic Firms Benefit from Foreign: s.n.

19. Iqbal, N, Ahmad, N, Haider, Z \& Anwar, S. (2014). Impact of foreign direct. s.1.: International Letters.

20. KHALID, M. A. (2016). The Impact of Trade Openness on Economic Growth in the Case of Turkey. s.1.: Research Journal of Finance and Accounting ISSN 2222-1697 (Paper) ISSN 2222-2847 (Online).

21. Levich, R. M \& Rizzo, R. C, (1998). Alternative Tests for Time Series Dependence Based on Autocorrelation Coefficients. s.l.: Working Paper Series-New York University Salomon Center S.

22. Lucas, R. (1988). The mechanics of economic development. J. Monetary Econ. s.l.: 22, 3-42.

23. Mahmoud, L. O. M. (2015). Consumer Price Index and Economic Growth: a Case Study of Mauritania 1990 - 2013. s.1.: Asian Economic and Social Society.

24. Marilyne Huchet-Bourdon, Chantal L. M. \& Mariana, V., n.d. The relationship between trade openness and economic growth: Some new insights on the openness measurement issue. s.l.s.n.

25. Nikolaos, D. Erotokritos, V. \& Antonios, A., n.d. The Main Determinants of Economic Growth: an Empirical Investigation With Granger Causality. s.l.s.n.

26. Pigato, M. A. (2014). Benin Economics Update Fall 2014, 3.

27. Rafael, A. María, I. b. \& Pablo P. (2017). Foreign direct investment and economic growth in Latin America. s.l.: Economic Analysis and Policy.

28. Rana, R. H. (2014). Government Expenditure and Economic Growth in Bangladesh: an Empirical Study. s.1.: The International Journal of Business \& Management.

29. Raziiakhan, A., Damira, B. \& Junus, G., (2007). Relationship between Government Expenditure and Economic Growth in Transition Countries: Case of Kyrgyzstan and Tajikistan. s.l: s.n.

30. Sandalcilar, A. R. \&. A. A. (2012). Foreign Direct Investment and Gross Domestic Product: an Application on ECO Region (1995-2011). Special issue, International Journal of Business and Social Science, 3(22), E189- 98.

31. Tan, B. T. C. (2016). Examining the causal linkages among domestic investment, FDI, trade, interest rate and economic growth in ASEAN-5 countries. J. Econ. Financ. Issues 6, 214-220.

32. Temple, J. (1999). The new growth evidences. s.1.: Journal of Economic.

33. Tounde Paterne, D. K. Z. I. B. \& Gbongl, I. K. (2016). Impact of the Foreign Direct Investment on Economic Growth in Benin: a Cointegration Analysis. School of Management \& Economics, University of Electronic Science \& Technology of China (UESTC).

34. United Nations, A., November 27. (1987). The United Nations International Conference of promotion for code of conduct for technology transfer.

35. Wajahat Ali \& Azrai Abdullah. (2015). The Impact of Trade Openness on the Economic Growth of Pakistan: 1980-2010. Global Business and Management Research: an International Journal 7(2), (2015.

36. Zhao, H. (1995). Technology Imports and Their Impacts on the Enhancement of China's. The journal of Development Studies, 31, 585-602.

\section{Appendix}

Table 1. Original model

\begin{tabular}{|c|c|c|c|c|}
\hline \multicolumn{5}{|c|}{ Dependent Variable: LOGGDP } \\
\hline \multicolumn{5}{|c|}{ Method: Least Squares } \\
\hline \multicolumn{5}{|c|}{ Date: $12 / 18 / 18$ Time: $15: 58$} \\
\hline \multicolumn{5}{|c|}{ Sample (adjusted): 19712017} \\
\hline \multicolumn{5}{|c|}{ Included observations: 47 after adjustments } \\
\hline $\begin{array}{r}\text { Variable } \\
\end{array}$ & Coefficient & Std. Error & t-Statistic & Prob. \\
\hline $\mathrm{C}$ & 2.103171 & 0.242000 & 8.690794 & 0.0000 \\
\hline LOGFDI & 21.76442 & 0.636005 & 34.22053 & 0.0000 \\
\hline LOGTO & -1.491208 & 0.137423 & -10.85125 & 0.0000 \\
\hline LOGGOV & -37.02539 & 1.369394 & -27.03780 & 0.0000 \\
\hline LOGCPI & 17.35084 & 0.823492 & 21.06983 & 0.0000 \\
\hline R-squared & 0.999983 & \multicolumn{2}{|c|}{ Mean dependent var } & 2.904530 \\
\hline Adjusted R-squared & 0.999981 & \multicolumn{2}{|c|}{ S.D. dependent var } & 0.893962 \\
\hline S.E. of regression & 0.003869 & \multicolumn{2}{|c|}{ Akaike info criterion } & -8.171424 \\
\hline Sum squared resid & 0.000629 & \multicolumn{2}{|c|}{ Schwarz criterion } & -7.974600 \\
\hline Log likelihood & 197.0285 & \multicolumn{2}{|c|}{ Hannan-Quinn criter. } & -8.097358 \\
\hline F-statistic & 613990.5 & \multicolumn{2}{|c|}{ Durbin-Watson stat } & 1.322465 \\
\hline Prob(F-statistic) & 0.000000 & & & \\
\hline
\end{tabular}

Source: author from Eviews. 
Table 2. Cointegreation test

Dependent Variable: LOGGDP

Method: Fully Modified Least Squares (FMOLS)

Date: 12/18/18 Time: 16:06

Sample (adjusted): 19712017

Included observations: 47 after adjustments

Cointegrating equation deterministics: $\mathrm{C}$

Long-run covariance estimate (Bartlett kernel, Newey-West fixed bandwidth

\begin{tabular}{|c|c|c|c|c|}
\hline \multicolumn{3}{|l|}{$=4.0000)$} & \multirow[b]{2}{*}{ t-Statistic } & \multirow[b]{2}{*}{ Prob. } \\
\hline Variable & Coefficient & Std. Error & & \\
\hline LOGFDI & 21.59522 & 0.737500 & 29.28164 & 0.0000 \\
\hline LOGTO & -1.396873 & 0.159353 & -8.765899 & 0.0000 \\
\hline LOGGOV & -36.57065 & 1.587926 & -23.03045 & 0.0000 \\
\hline LOGCPI & 17.00824 & 0.954907 & 17.81140 & 0.0000 \\
\hline $\mathrm{C}$ & 1.916652 & 0.280619 & 6.830088 & 0.0000 \\
\hline R-squared & 0.999982 & \multicolumn{2}{|c|}{ Mean dependent var } & 2.904530 \\
\hline Adjusted R-squared & 0.999980 & \multicolumn{2}{|c|}{ S.D. dependent var } & 0.893962 \\
\hline S.E. of regression & 0.003958 & \multicolumn{2}{|c|}{ Sum squared resid } & 0.000658 \\
\hline Durbin-Watson stat & 1.232414 & \multicolumn{2}{|c|}{ Long-run variance } & $2.01 \mathrm{E}-05$ \\
\hline
\end{tabular}

Source: author from Eviews.

Table 3. ARCH test

Dependent Variable: LOGGDP

Method: ML - ARCH (Marquardt) - Normal distribution

Date: 12/18/18 Time: 16:07

Sample (adjusted): 19712017

Included observations: 47 after adjustments

Convergence achieved after 1 iteration

Presample variance: backcast (parameter $=0.7)$

$\mathrm{GARCH}=\mathrm{C}(6)+\mathrm{C}(7)^{*} \mathrm{RESID}(-1)^{\wedge} 2+\mathrm{C}(8) * \operatorname{GARCH}(-1)$

\begin{tabular}{|c|c|c|c|c|}
\hline Variable & Coefficient & Std. Error & z-Statistic & Prob. \\
\hline $\mathrm{C}$ & 2.103173 & 0.209724 & 10.02831 & 0.0000 \\
\hline LOGFDI & 21.76442 & 0.063972 & 340.2196 & 0.0000 \\
\hline LOGTO & -1.491208 & 0.090294 & -16.51497 & 0.0000 \\
\hline LOGGOV & -37.02538 & 0.008230 & -4498.930 & 0.0000 \\
\hline \multirow[t]{2}{*}{ LOGCPI } & 17.35084 & 0.111429 & 155.7125 & 0.0000 \\
\hline & \multicolumn{2}{|c|}{ Variance Equation } & & \\
\hline $\mathrm{C}$ & $8.49 \mathrm{E}-06$ & $2.53 \mathrm{E}-05$ & 0.335159 & 0.7375 \\
\hline $\operatorname{RESID}(-1)^{\wedge} 2$ & 0.149999 & 0.702084 & 0.213648 & 0.8308 \\
\hline $\operatorname{GARCH}(-1)$ & 0.599996 & 1.128337 & 0.531753 & 0.5949 \\
\hline R-squared & 0.999983 & \multicolumn{2}{|c|}{ Mean dependent var } & 2.904530 \\
\hline Adjusted R-squared & 0.999981 & \multicolumn{2}{|c|}{ S.D. dependent var } & 0.893962 \\
\hline S.E. of regression & 0.003869 & \multicolumn{2}{|c|}{ Akaike info criterion } & -8.023277 \\
\hline Sum squared resid & 0.000629 & \multicolumn{2}{|c|}{ Schwarz criterion } & -7.708358 \\
\hline Log likelihood & 196.5470 & \multicolumn{2}{|c|}{ Hannan-Quinn criter. } & -7.904771 \\
\hline Durbin-Watson stat & 1.322435 & & & \\
\hline
\end{tabular}

Source: author from Eviews.

Table 4 cointegration test between GDP and FDI

Date: 12/19/18 Time: 22:01

Sample (adjusted): 19732017

Included observations: 45 after adjustments

Trend assumption: Quadratic deterministic trend

Series: LOGGDP LOGFDI

Lags interval (in first differences): 1 to 1

Hypothesized

Unrestricted Cointegration Rank Test (Trace)

No. of CE(s)

None *

At most $1 *$

Eigenvalue
1.000000
0.907239

Trace

Statistic

1000.866

106.9976

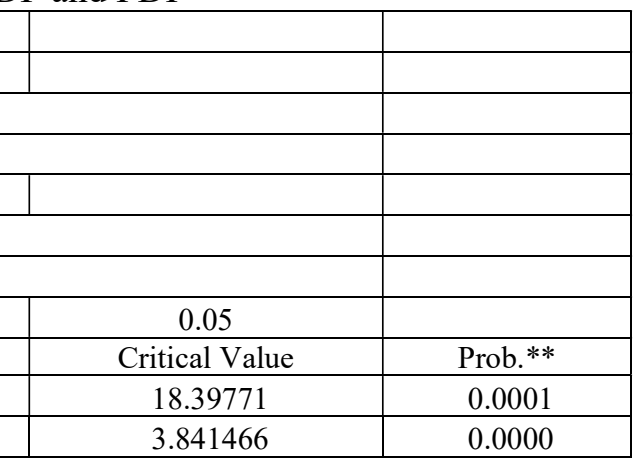


Table 4 (cont.). Cointegration test between GDP and FDI

Trace test indicates 2 cointegrating eqn(s) at the 0.05 level

$*$ denotes rejection of the hypothesis at the 0.05 level

**MacKinnon-Haug-Michelis (1999) p-values

Hypothesized

Unrestricted Cointegration Rank Test (Maximum Eigenvalue)

No. of CE(s)

None *

At most $1 *$

\begin{tabular}{c|c} 
& Max-Eigen \\
\hline Eigenvalue & Statistic \\
\hline 1.000000 & 893.8684 \\
0.907239 & 106.9976
\end{tabular}

Max-eigenvalue test indicates 2 cointegrating eqn(s) at the 0.05 level

$*$ denotes rejection of the hypothesis at the 0.05 level

**MacKinnon-Haug-Michelis (1999) p-values

\begin{tabular}{|l|c|c|c|c|}
\hline \multicolumn{5}{|c|}{ Unrestricted Cointegrating Coefficients (normalized by $\left.\mathrm{b}^{\prime *} \mathrm{~S} 11^{*} \mathrm{~b}=\mathrm{I}\right):$} \\
\hline LOGGDP & LOGFDI & & & \\
\hline 1385.801 & -1385.839 & & & \\
\hline 3253.941 & -3157.329 & & & \\
\hline Unrestricted Adjustment Coefficients (alpha): & -0.000697 & $-1.42 \mathrm{E}-06$ & & \\
\hline D(LOGGDP) & 0.000460 & $-5.43 \mathrm{E}-05$ & & \\
\hline D(LOGFDI) & Log likelihood & 1085.311 & \\
\hline \multicolumn{7}{|l|}{ 1 Cointegrating Equation(s): }
\end{tabular}

Normalized cointegrating coefficients (standard error in parentheses)

\begin{tabular}{|c|c|}
\hline LOGGDP & LOGFD \\
\hline 1.000000 & -1.000027 \\
\hline & $(2.1 \mathrm{E}-07)$ \\
\hline
\end{tabular}

Adjustment coefficients (standard error in parentheses)

D(LOGGDP)

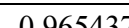

$-0.965437$

$(0.00033)$

D(LOGFDI)

0.637771

$(0.01250)$

Source: author from Eviews.

Table 5. Cointegration test between GDP and CPI

Date: $12 / 19 / 18$ Time: $22: 10$

Sample (adjusted): 19732017

Included observations: 45 after adjustments

Trend assumption: Quadratic deterministic trend

Series: LOGGDP LOGCPI

Lags interval (in first differences): 1 to 1

Unrestricted Cointegration Rank Test (Trace)

Hypothesized

No. of CE(s)

None *

At most 1 *

Eigenvalue

0.999995

0.916682

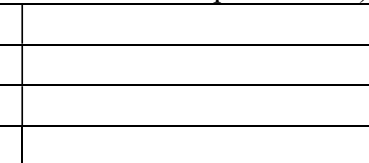

\begin{tabular}{|l|l|l|}
\hline & & \\
\hline & & \\
\hline & & \\
\hline & & \\
\hline & & \\
\hline
\end{tabular}

Trace test indicates 2 cointegrating eqn(s) at the 0.05 level

$*$ denotes rejection of the hypothesis at the 0.05 level

**MacKinnon-Haug-Michelis (1999) p-values

Unrestricted Cointegration Rank Test (Maximum Eigenvalue)

\begin{tabular}{|c|c|c|c|c|}
\hline Hypothesized & & Max-Eigen & 0.05 & \\
\hline No. of CE(s) & Eigenvalue & Statistic & Critical Value & Prob.** \\
\hline None $*$ & 0.999995 & 548.5939 & 17.14769 & 0.0001 \\
\hline At most $1 *$ & 0.916682 & 111.8292 & 3.841466 & 0.0000 \\
\hline
\end{tabular}

Max-eigenvalue test indicates 2 cointegrating eqn(s) at the 0.05 level

$*$ denotes rejection of the hypothesis at the 0.05 level

**MacKinnon-Haug-Michelis (1999) p-values

Unrestricted Cointegrating Coefficients (normalized by $b^{\prime * S 11 * b=I): ~}$

\begin{tabular}{|c|c|c|c|c|}
\hline Unrestricted Cointegrating Coefficients (normalized by $\left.\mathrm{b}^{*} * \mathrm{~S} 11 * \mathrm{~b}=\mathrm{I}\right):$ & & \\
\hline LOGGDP & LOGCPI & & & \\
\hline 230.3076 & -233.7367 & & & \\
\hline 568.0237 & -398.5442 & & & \\
\hline Unrestricted Adjustment Coefficients (alpha): & -0.001833 & -0.000133 & & \\
\hline D(LOGGDP) & & & \\
\hline
\end{tabular}


Table 5 (cont.). Cointegration test between GDP and CPI

\begin{tabular}{|l|c|c|c|c|}
\hline \multicolumn{1}{|c|}{ D(LOGCPI) } & 0.000170 & $-2.63 \mathrm{E}-05$ & \\
\hline 1 Cointegrating Equation(s): & Log likelihood & 885.5150 & \\
\hline Normalized cointegrating coefficients (standard error in parentheses) & & \\
\hline LOGGDP & LOGCPI & & \\
\hline 1.000000 & -1.014889 & & \\
\hline \multicolumn{2}{|l|}{$(0.00010)$} & & \\
\hline Adjustment coefficients (standard error in parentheses) & & \\
\hline D(LOGGDP) & -0.422163 & & \\
\hline \multicolumn{2}{|l|}{} & $(0.00504)$ & & \\
\hline D(LOGCPI) & 0.039264 & & \\
\hline
\end{tabular}

Source: author from Eviews.

Table 6. Cointegration test between GDP and TO

Date: $12 / 19 / 18$ Time: $22: 12$

Sample (adjusted): 19732017

Included observations: 45 after adjustments

Trend assumption: Quadratic deterministic trend

Series: LOGGDP LOGTO

Lags interval (in first differences): 1 to 1

Unrestricted Cointegration Rank Test (Trace)

Hypothesized

No. of CE(s)

None *

Eigenvalue

At most $1 *$

0.999912

0.950718

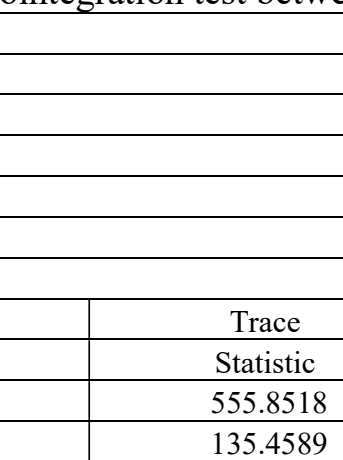

\begin{tabular}{l|l|l|} 
& \\
& & \\
& & \\
\hline \multicolumn{2}{|l|}{} & \\
\hline & 0.05 & \\
\hline & Critical Value & Prob.** \\
\hline & 18.39771 & 0.0001 \\
\hline & 3.841466 & 0.0000 \\
\hline
\end{tabular}

Trace test indicates 2 cointegrating eqn(s) at the 0.05 level

$*$ denotes rejection of the hypothesis at the 0.05 level

**MacKinnon-Haug-Michelis (1999) p-values

Unrestricted Cointegration Rank Test (Maximum Eigenvalue)

\begin{tabular}{|c|c|c|c|c|}
\hline Hypothesized & & Max-Eigen & 0.05 & \\
\hline No. of CE(s) & Eigenvalue & Statistic & Critical Value & Prob. $^{* *}$ \\
\hline None & 0.999912 & 420.3929 & 17.14769 & 0.0001 \\
\hline At most $1 *$ & 0.950718 & 135.4589 & 3.841466 & 0.0000 \\
\hline
\end{tabular}

Max-eigenvalue test indicates 2 cointegrating eqn(s) at the 0.05 level

$*$ denotes rejection of the hypothesis at the 0.05 level

**MacKinnon-Haug-Michelis (1999) p-values

Unrestricted Cointegrating Coefficients (normalized by $\mathrm{b}^{\prime * \mathrm{~S} 11} \mathrm{*} \mathrm{b}=\mathrm{I}$ ):

\begin{tabular}{|c|c|c|c|c|}
\hline LOGGDP & LOGTO & & & \\
\hline-20.99904 & 567.8476 & & & \\
\hline-90.91888 & -2595.204 & & & \\
\hline Unrestricted Adjustment Coefficients (alpha): & 0.003931 & 0.001509 & & \\
\hline D(LOGGDP) & $-1.32 \mathrm{E}-06$ & $1.91 \mathrm{E}-07$ & & \\
\hline D(LOGTO) & & Log likelihood & 968.5463 & \\
\hline 1 Cointegrating Equation(s):
\end{tabular}

Normalized cointegrating coefficients (standard error in parentheses)

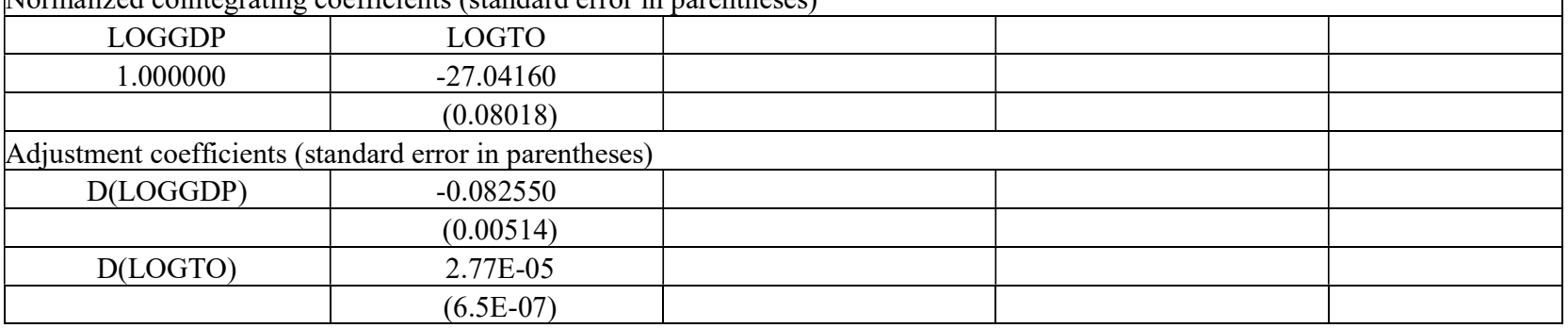

Source: author from Eviews.

Table 7. Cointegration test between GDP and GOV

Date: $12 / 19 / 18$ Time: $22: 13$

Sample (adjusted): 19732017

Included observations: 45 after adjustments 
Table 7 (cont.). Cointegration test between GDP and GOV

Trend assumption: Quadratic deterministic trend

Series: LOGGDP LOGGOV

Lags interval (in first differences): 1 to 1

Unrestricted Cointegration Rank Test (Trace)

Hypothesized

No. of CE(s)

None *

At most $1 *$

Eigenvalue
0.999999
0.910646

Trace

Statistic

Statistic

108.6816

Trace test indicates 2 cointegrating eqn(s) at the 0.05 level

$*$ denotes rejection of the hypothesis at the 0.05 level

**MacKinnon-Haug-Michelis (1999) p-values

Unrestricted Cointegration Rank Test (Maximum Eigenvalue)

\begin{tabular}{|c|c|c|c|c|}
\hline Hypothesized & & Max-Eigen & 0.05 & \\
\hline No. of CE(s) & Eigenvalue & Statistic & Critical Value & Prob.** \\
\hline None $*$ & 0.999999 & 642.5663 & 17.14769 & 0.0001 \\
\hline At most $1 *$ & 0.910646 & 108.6816 & 3.841466 & 0.0000 \\
\hline
\end{tabular}

Max-eigenvalue test indicates 2 cointegrating eqn(s) at the 0.05 level

$*$ denotes rejection of the hypothesis at the 0.05 level

**MacKinnon-Haug-Michelis (1999) p-values

Unrestricted Cointegrating Coefficients (normalized by $\mathrm{b}^{\prime * \mathrm{~S}} 11 * \mathrm{~b}=\mathrm{I}$ )

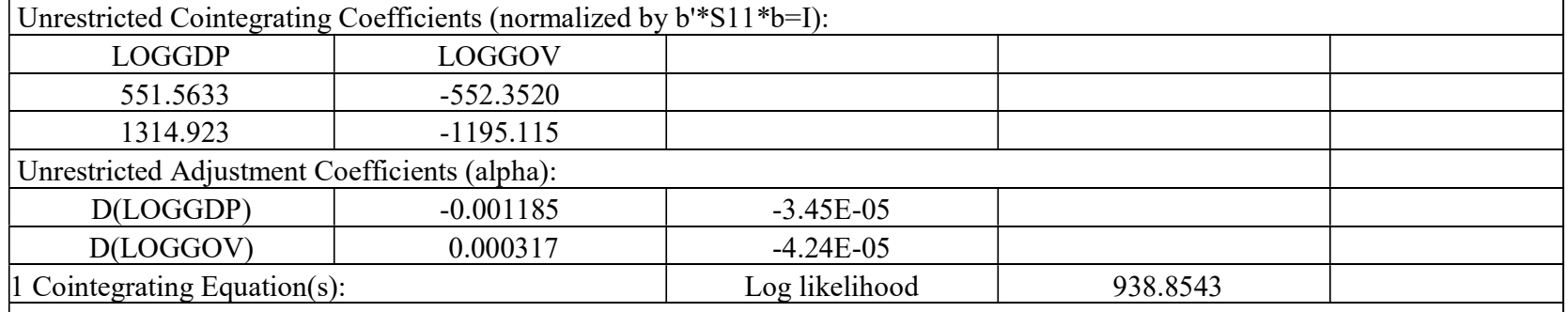

Normalized cointegrating coefficients (standard error in parentheses)

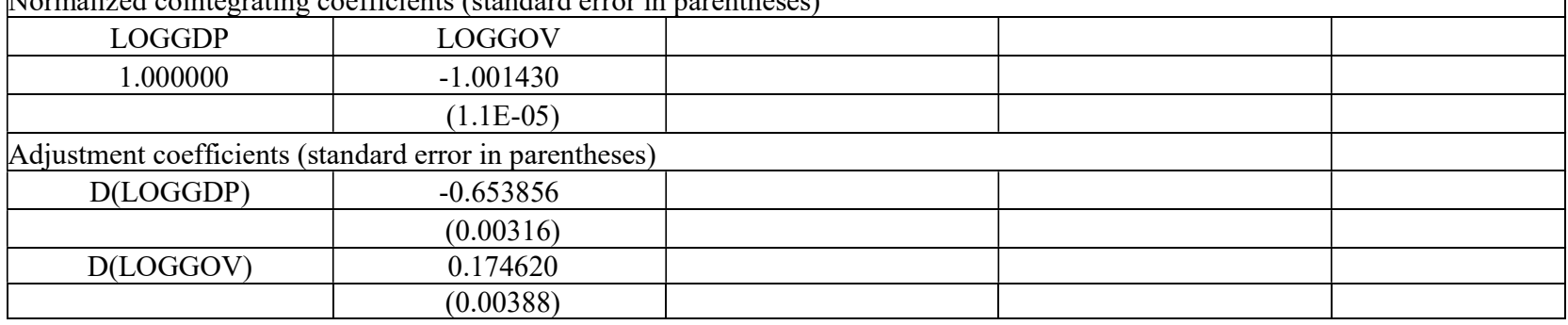

\section{RESID}

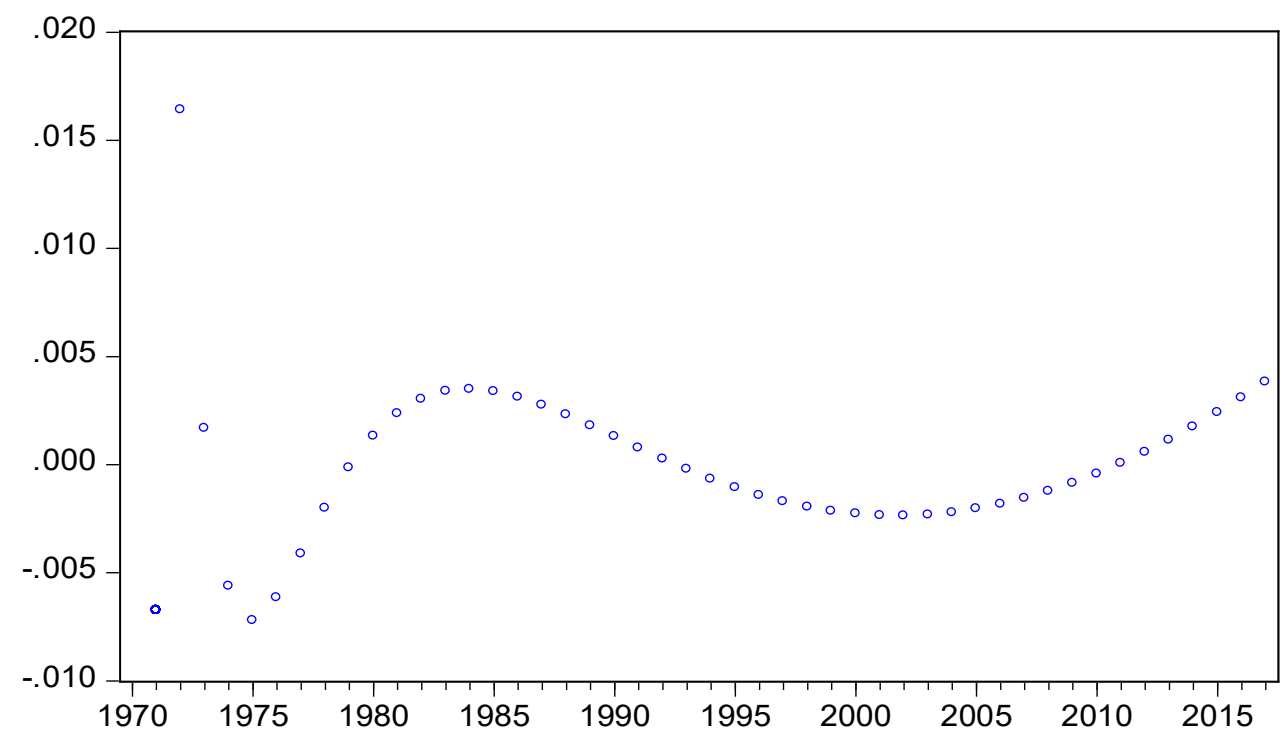

Figure 1. Normal distributed 


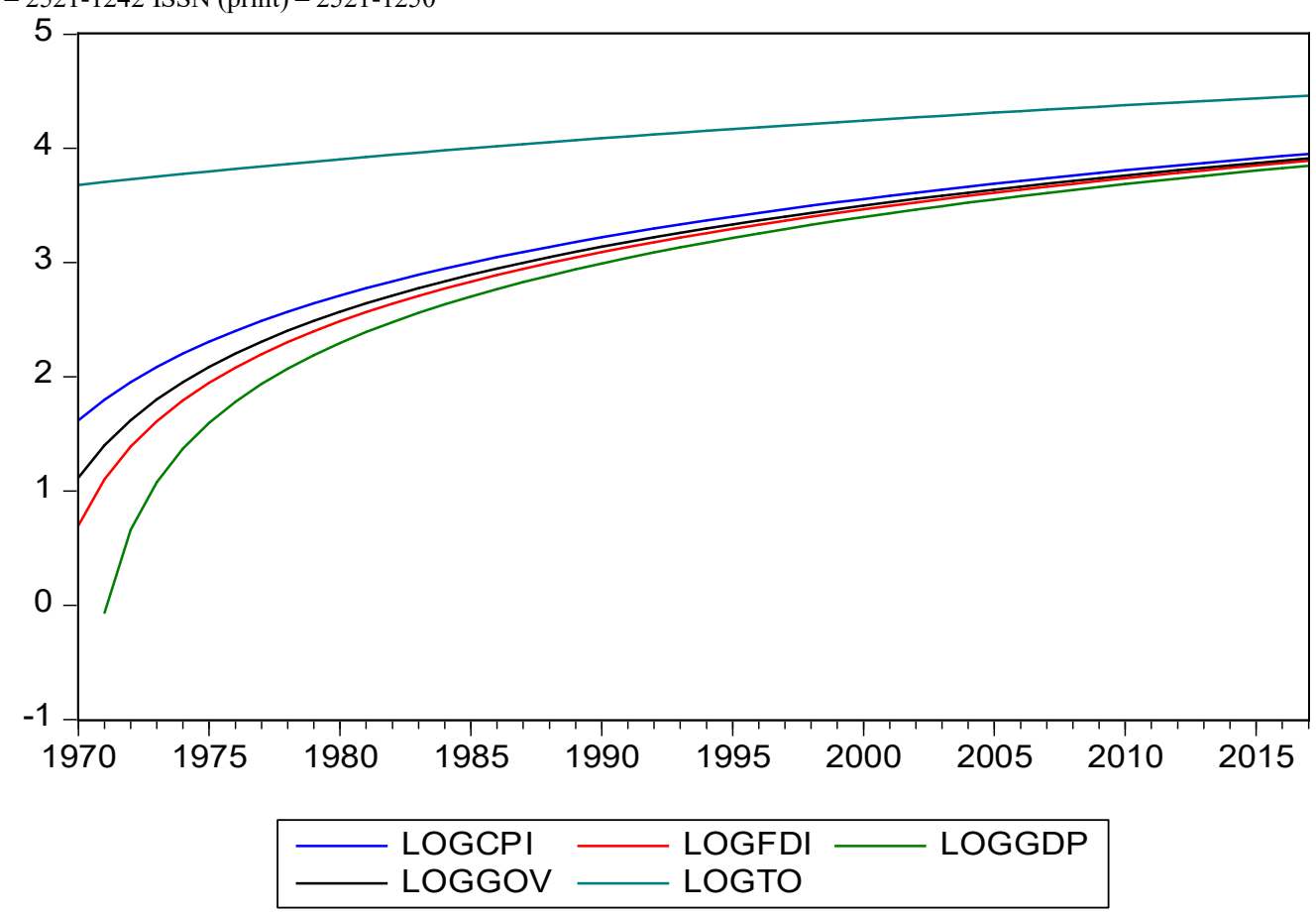

Figure 2. Stationary (line and symbol) from Eviews 